\title{
Jagoda Budzik
}

Uniwersytet Wrocławski https://orcid.org/0000-0002-6287-8340

jagoda.budzik@uwr.edu.pl

\section{Literatura jako strategia przetrwania. Przypadek Węgier}

\section{Kinga Piotrowiak-Junkiert, Od idylli do ironii. Literatura węgierska wobec Zagłady w latach 1944-1948, Poznań: Wydawnictwo Naukowe UAM, 2021, 296 s.}

Wielojęzyczność Zagłady, będąca symptomem jej kulturowego, narodowościowego i geograficznego zróżnicowania, implikuje różnorodność znaczeń, które Szoa przybierała dla ofiar doświadczających jej w różnych miejscach Europy. Różnorodność językowa sprawiła także, że reprezentacje Zagłady stały się częścią dziedzictwa większości kultur europejskich.

W najdobitniejszy sposób wielojęzyczność ta została sportretowana w monumentalnym Shoah Claude'a Lanzmanna, w szczególności za sprawą stałej obecności tłumaczki podczas rozmów przeprowadzanych przez reżysera z bohaterami. Zabieg ten unaocznił konieczność podejmowania ciągłych mediacji między różnymi kontekstami językowymi, stawiając je za konieczny do spełnienia warunek opowiadania o Zagładzie w sposób ukazujący jej nieskończoną złożoność. Co znaczące, i na co zwraca uwagę Dorota Głowacka, kolejnym i jedynym dziełem filmowym, które wyeksponowało tę właściwość Zagłady, był film Syn Szawła (2015) węgierskiego reżysera László Nemesa ${ }^{1}$. W obrazie tym jednak w przeciwieństwie do Shoah język węgierski nie tylko był w opowieści obecny, ale też - na tle całej gamy innych języków, którymi posługują się bohaterowie stanowił jej podstawowy budulec.

Świadectwem wielojęzyczności Zagłady oraz jej konsekwencji kulturowych jest dla polskiego czytelnika także książka Od idylli do ironii. Literatura węgierska wobec Zagłady w latach 1944-1948, która stanowi najpełniejsze i zarazem najbardziej syntetyczne wydane po polsku opracowanie dotyczące literatury węgierskiej poświęconej Zagładzie. Autorka, Kinga Piotrowiak-Junkiert, hun-

${ }^{1}$ Dorota Głowacka, Współ-pamięć, pamięć negatywna i dylematy przekładu w „wycinkach” z „Shoah” Claude'a Lanzmanna, „Teksty Drugie” 2016, nr 6, s. 301. 
garystka, literaturoznawczyni oraz - co nie bez znaczenia - tłumaczka i poetka, analizuje w pracy teksty literackie (najczęściej zupełnie w Polsce nieznane) rozmaitej proweniencji gatunkowej autorstwa węgierskich pisarzy i pisarek żydowskiego pochodzenia, napisane podczas wojny lub krótko po jej zakończeniu. Taki zakres czasowy rozważań jest podyktowany specyfiką sytuacji na Węgrzech - zajęciem ich przez Trzecią Rzeszę w roku 1944 i radykalną przemianą, która miała nastąpić w obszarze literatury węgierskiej po roku 1948 (s. 25). Wybór omawianych dzieł, jak pisze autorka, ma na celu „prezentację pełnej panoramy doświadczeń pisarzy żydowskich: deportacji do obozu, prac przymusowych (w kraju i poza jego granicami), pobytu w getcie i ukrywania się podczas oblężenia Budapesztu" (s. 25). Autorka wykonała zatem bezcenną pracę, nie tylko przybliżając polskiemu odbiorcy teksty o dużej wartości artystycznej i poznawczej, lecz także rozszerzając jego perspektywę spoglądania na funkcje literatury zagładowej w pierwszych latach jej powstawania.

Książka Kingi Piotrowiak-Junkiert jest bowiem czymś więcej, niż zapowiada jej podtytuł. W istocie to także znakomicie napisana i dająca się czytać jednym tchem opowieść o historii węgierskich Żydów i bolesnej naturze ich związków z ojczyzną ${ }^{2}$, dziejach literatury węgierskiej, a nade wszystko o tym, jak twórczość literacka w obliczu kryzysów staje się podstawowym medium pamięci o doświadczeniach granicznych. Za sprawą licznych odniesień do recepcji i wydawniczych losów przywoływanych pozycji autorka przedstawia je jako „literaturę mimo wszystko"3 ${ }^{3}$, której pisanie uznać można nie tylko za próbę wyrażenia indywidualnych doświadczeń, lecz także za uniwersalny gest antytotalitarny (zarówno w odniesieniu do realiów wojny, jak i sytuacji panującej na powojennych Węgrzech).

Od idylli do ironii jest także opowieścią zmuszającą polskiego czytelnika do weryfikacji znanych schematów myślowych i nawyków skojarzeniowych- zarówno w sferze wyobrażeń na temat przebiegu Zagłady, jak i na poziomie periodyzacji związanej z nią literatury. W pierwszym przypadku dzieje się tak z uwagi na wyraźnie różniący się od warunków polskich zakres czasowy Zagłady węgierskich Żydów. Węgry, co niejednokrotnie podkreśla Piotrowiak-Junkiert, zostały zajęte przez Trzecią Rzeszę dopiero w marcu 1944 r., wcześniej ludność żydowska podlegała instytucjonalnym represjom ze strony rządu węgierskiego (znakowanie, praca przymusowa), a także była obiektem systematycznej przemocy antysemickiej ze strony węgierskiego społeczeństwa. Późne w stosunku do reszty Europy zajęcie Węgier przez wojska niemieckie dało węgierskiej literaturze dodatkowe lata, w których „obserwowano jeden z najbardziej dynamicznych

\footnotetext{
${ }^{2}$ Najbardziej znane oblicze tej relacji to obraz wyłaniający się z pisarstwa Imrego Kertésza, zob. np. Imre Kertész, Budapeszt - niepotrzebne wyznanie [w:] idem, Język na wygnaniu, tłum. Elżbieta Sobolewska, Warszawa: W.A.B, 2004, s. 129-136.

${ }^{3}$ Parafrazuję tu tytuł książki Georges'a Didi-Hubermana - Obrazy mimo wszystko, tłum. Maja Kubiak Ho-Chi, Kraków: Universitas, 2012.
} 
procesów artystycznych w Europie Środkowo-Wschodniej, prawdziwy rozkwit literatury modernistycznej, w której nieocenioną rolę odegrali pisarze żydowscy" (s. 20). Podkreślając odmienność doświadczeń pisarzy żydowskich na Węgrzech (jak zaznacza autorka, ukazanie pełnej ich gamy jest jednym z głównych celów książki) względem doświadczeń twórców z Polski i innych państw Europy, badaczka zarazem kilkukrotnie rysuje paralele między lokalnym kontekstem węgierskim a kontekstem polskim lub kontekstem globalnej pamięci Zagłady i jej reprezentacji.

W drugim przypadku autorka wskazuje na błędne założenia Judith Tydor Baumel (i innych) na temat gatunków dominujących w pierwszej fazie pisarstwa o Zagładzie. Jak bowiem stwierdza izraelska badaczka, tym, co charakteryzowało pierwsze utwory o tematyce obozowej, było dążenie do autentyczności rozumianej jako kronikarska sprawozdawczość, co miało się przejawiać w popularności gatunków takich jak dziennik, relacja czy reportaż (s. 21, 67). Analizowane w książce utwory (podobnie zresztą jak wiele tekstów literatury polskiej pisanych tuż po wojnie) są jednak przykładem na to, że literacka artykulacja doświadczenia Szoa może (i poniekąd musi) stać się przestrzenią eksperymentów.

Autorka sięga - w zależności od potrzeb - po różne narzędzia badawcze. Oprócz wykorzystania szeroko rozumianych narzędzi literaturoznawczych Piotrowiak-Junkiert sięga po metody gender studies i posthumanistyki. W ten sposób Od idylli do ironii staje się cennym uzupełnieniem dyskusji toczących się w szerokim kontekście studiów nad Zagładą w ostatnich dekadach. Książka stwarza także przestrzeń do wybrzmienia głosów, które przez lata były w badaniach marginalizowane lub pomijane, a z pewnością nie uwzględniano ich przy budowaniu uniwersalizujących obrazów doświadczenia Zagłady, a zatem sytuujących się „na obrzeżach narracji o zwykłym człowieku” (s. 202) - głosów kobiet (ze zwróceniem uwagi na różnorodność ich doświadczeń), dzieci, zwierząt, a także świata natury.

Wspomniane wyżej założenie ukazania możliwie pełnej panoramy żydowskich losów na Węgrzech podczas Zagłady stanowi zarazem klucz kompozycyjny książki, która każdemu twórcy poświęca osobny rozdział. Zasadniczą część rozważań poprzedza rozdział prezentujący historyczny i literacki kontekst powstania omawianych dzieł, który pozwala dostrzec długie trwanie antysemityzmu na Węgrzech, a także zrozumieć analizowane później zmagania autorów i autorek z żydowską tożsamością, przyjmowaną pod przymusem lub na własnych warunkach. Dzięki tej części rozważań łatwiej zrozumieć również procesy, których efektem była omawiana w książce literatura.

W pierwszym rozdziale autorka skupia się na powieści Wyzwalające się kobiety. Pierwsze 24 godziny wolności ${ }^{4}$ autorstwa Teréz Rudnóy (1946), publikacji

${ }^{4}$ Dla wygody czytelnika posługuję się polskimi tłumaczeniami tytułów, również w sytuacjach, gdy teksty nie ukazały się w tłumaczeniu na język polski (wówczas tłumaczenia pochodzą od Kingi Piotrowiak-Junkiert). 
będącej pierwszym zapisem doświadczeń obozowych w literaturze węgierskiej (co znamienne, jak zaznacza Piotrowiak-Junkiert, pisanym z perspektywy Węgierki, Żydówki i kobiety - s. 60). Powieść, do której opisu autorka ukuła funkcjonalne pojęcie „narracja oszczędzająca” (s. 68), przede wszystkim za sprawą zaznaczonego w podtytule zakresu czasowego fabuły, lokuje się daleko poza konwencją relacjonowania faktów. Analizując dzieło Rudnóy, autorka Od idylli do ironii nie tylko zwraca uwagę na genderowy wymiar doświadczenia narratorki, nadający tekstowi zasadniczy bieg, lecz także odnosi się do kwestii związanych z cielesnością oraz formułowaniem na nowo własnej tożsamości po wyzwoleniu.

Następnie Piotrowiak-Junkiert omawia twórczość poety Miklósa Radnotiego, którego cykl dziesięciu wierszy pisanych podczas marszu śmierci oraz w serbskim obozie w Bor został odnaleziony w niewielkim notesie razem ze zwłokami pisarza w masowym grobie podczas ekshumacji dwa lata po zakończeniu wojny. Do końca życia poeta trzymał się restrykcyjnych ram formalnych (swoje wiersze pisał heksametrem) i bukolicznej stylistyki, a konwencja ta niespodziewanie pozwoliła mu sformułować nieoczywiste diagnozy dotyczące ludzkiej kondycji w sytuacji granicznej. Badaczka w swojej analizie twórczości Randotiego zapełnia też ważną lukę interpretacyjną, szczególną uwagę poświęcając silnie obecnym w jego wierszach (a mimo to dotąd nieomawianym) wątkom zwierzęcym (s. 118).

Bohaterem kolejnego rozdziału jest Ernő Szép, autor reportażu lirycznego Woń człowieka (1945). Szép opisuje w nim doświadczenie zesłania na roboty przymusowe, a Kinga Piotrowiak-Junkiert zwraca uwagę na kształtującą ten zapis ironię obecną w tytule. Także w przypadku Szépa istotną funkcję w kreowaniu świata przedstawionego pełni natura. Jak zauważa autorka, „Podobnie jak u Randótiego, u Szépa natura nigdy nie jest scenografią śmierci i klęski ludzkiego życia, ale źródłem wiecznego, odrobinę egzaltowanego zdumienia i zachwytu nad istnieniem" (s. 147). Obydwaj autorzy czynią także ważnym tematem swojej twórczości kwestię żydowskiej tożsamości, nie zawsze przyjmowanej dobrowolnie, często narzucanej przez okoliczności.

Ciąg dalszy rozważań na temat relacji autorów z ich żydowską tożsamością przynosi analiza Dziennika oblężenia oraz cyklu poetyckiego Od marca do marca autorstwa Istvána Vasa. Twórczość Vasa stanowić ma kolejny przykład wyrazistego stylistycznie literackiego świadectwa wojennych przeżyć, w poczet których włączone zostaje także ukrywanie się w mieszkaniu nieżydowskich przyjaciół.

Bodaj najdobitniejszym przykładem funkcjonalnego wykorzystania osiągnięć literatury modernistycznej do budowania narracji o doświadczeniu Zagłady jest w ujęciu autorki surrealny poemat Ze snów umarłej Stefánii Mándy. Piotrowiak-Junkiert, zwracając uwagę na intertekstualność dzieła, wskazuje na paralelność procesów zachodzących w narracjach o Zagładzie z obszaru literatury i sztuk wizualnych. W tym miejscu należy dodać, że na szczególną uwagę 
zasługuje rola, jaką w rozważaniach badaczki odgrywa twórczość pisarek. Nie została ona, jak często się zdarza, zbiorczo ulokowana w kategorii „kobiecego doświadczenia Zagłady", ale stanowi pełnoprawny i równorzędny (choć przecież nie identyczny) z męskim głos opowieści o żydowskich przeżyciach.

Fakt ten wybrzmiewa w książce raz jeszcze w rozdziale poświęconym dwóm dziennikom, pisanym przez nastolatkę i kobietę w ciąży - Evę Heyman i Annę Dévényi. Obie relacje z różnych perspektyw wskazują na wielość znaczeń, które może przyjmować kategoria „kobiecego doświadczenia Zagłady” i w związku z tym na niemożność narzucenia mu jednolitej perspektywy. Autorka wskazuje też na pokoleniowe zróżnicowanie w doświadczeniu Zagłady, przywołując za Susan Rabin Suleiman kategorię pokolenia 1,5, odnoszącą się do tych, którzy przeżyli Zagładę jako dzieci (s. 210).

W ostatnim rozdziale książki, poświęconym utworom Naród lagrów i Voronyezs Istvána Örkenyego, bodaj najwyraźniej uwidacznia się złożoność doświadczenia węgierskich Żydów, jego odmienność oraz niekiedy zawarty w nim paradoks. Örkeny, wysłany na prace przymusowe w zakolu Donu na froncie wschodnim, w styczniu $1943 \mathrm{r}$. wraz z węgierskimi żołnierzami dostał się do radzieckiej niewoli, w której przebywał do roku 1947. Pomimo tej pozornie radykalnej odmienności losu Örkenyego analiza jego twórczości odsłania jednak pewne topiczne podobieństwa między doświadczeniem lagru niemieckiego i radzieckiego obozu jenieckiego. W ten sposób pozwala spojrzeć na jedno i drugie z nowej perspektywy.

Co znamienne dla wszystkich utworów omawianych w pracy Kingi Piotrowiak-Junkiert oraz ich autorów i autorek (tych, którzy przeżyli), opisywane w nich doświadczenia nie dobiegają końca wraz z chwilą wyzwolenia. Sytuacja polityczna na Węgrzech, nałożone na większość autorów zakazy publikacji, a także silna tabuizacja tematu Zagłady Żydów sprawiły, że literatura ta, powstała w ostatnich chwilach względnej wolności twórczej, stanęła na straży wspomnień, które nie mogły zaistnieć w węgierskiej historiografii przez kolejne dekady. W ten sposób po raz kolejny uwidoczniła się różnica w funkcjonowaniu dyskursu historycznego i literackiego (oraz literaturoznawczego).

W tym ujęciu literatura objawia się jednak jako coś więcej niż nośnik pamięci. Jak stwierdza autorka, „Na stalinowskich Węgrzech w obliczu marginalizacji kwestii żydowskiej prawdę historyczną można było poznać wyłącznie dzięki literaturze (najczęściej podziemnej)" (s. 166). W ten sposób Od idylli do ironii stanowi przejmujące, bezcenne i rzetelne świadectwo tego, jak twórczość literacka staje się funkcjonalnym źródłem historycznym, narzędziem stawiania oporu, sejsmografem natychmiastowo wychwytującym zjawiska społeczne, a nade wszystko - strategią przetrwania. 